\title{
The Influencing Factors and Improvements of College Students' Abilities in Innovation and Entrepreneurship - From the Perspective of School and Society
}

Zhenbo Bao ${ }^{1, a^{*}, \text {,Hongjun Teng }}{ }^{2, b}$, Jinxing Peng ${ }^{1, c}$ and Xinyuan Liu ${ }^{1, d}$

${ }^{1}$ Engineering and Technology College, Tianjin Agricultural University, Tianjin, China, 300384

${ }^{2}$ Clinic, Tianjin Agricultural University, Tianjin, China, 300384

a*zhenbobao@sohu.com, bhongjun-teng@163.com, cpengjinxing@163.com, diuxinyuan@tjau.edu.cn

Keywords: Innovation and entrepreneurship; Influence factors; College students; Improvements

\begin{abstract}
The cultivation of college students' innovative and entrepreneurial abilities is closely related to school and society. From the school's point of view, the influencing factors of innovation and entrepreneurship capabilities, such as the innovation and entrepreneurship curriculum system to be improved, the innovation and entrepreneurship practice training system needs to be strengthened, etc. are analyzed, and the improvements of creating innovation and entrepreneurship education system, and strengthenning innovation and entrepreneurship education faculty team construction, etc. are put forward. From the society's point of view, the influencing factors of innovation and entrepreneurship capabilities, such as the society's innovative and entrepreneurial environment to be improved, and the lack of necessary family support, etc. are analyzed, and the improvements of establishing public professional service platform, and constructing innovation and entrepreneurship practice bases are put forward. Giving full play to the positive factors in school and society has positive significance in cultivating college students' innovative and entrepreneurial abilities.
\end{abstract}

\section{Introduction}

As a base practice site for cultivating innovative entrepreneurship talents, school and society play an important role in cultivating innovative entrepreneurship talents [1,2]. Colleges and society should make the cultivating of college students' innovation and entrepreneurship ability as an important task. From the point of view of the school and society, the factors influencing the innovation ability are analyzed and some improvement measures are put forward [3, 4].

\section{Analysis of Factors Affecting College Students' Innovation and Entrepreneurship from the Perspective of School}

The factors affecting college students' abilities in innovation and entrepreneurship from the perspective of school are shown in Table $1[2,3]$. 
Table 1 The factors affecting college students' abilities in innovation and entrepreneurship from the perspective of school

\begin{tabular}{|c|c|}
\hline Influencing factors & Specific description \\
\hline $\begin{array}{l}\text { ne innovation and } \\
\text { trepreneurship } \\
\text { rriculum system } \\
\text { colleges and } \\
\text { iiversities needs to }\end{array}$ & $\begin{array}{l}\text { The innovative and entrepreneurial disciplines of colleges and universities have } \\
\text { not formed systematically. There are fewer innovation and entrepreneurship } \\
\text { courses. Innovation and entrepreneurship education models need to be } \\
\text { implemented. The goal of talent cultivation for innovation and } \\
\text { entrepreneurship needs to be strengthened. In some universities, innovation } \\
\text { and entrepreneurship education is not linked to professional training. }\end{array}$ \\
\hline $\begin{array}{l}\text { University } \text { students' } \\
\text { innovation and } \\
\text { entrepreneurship } \\
\text { social practice } \\
\text { training system } \\
\text { needs to be } \\
\text { strengthened. }\end{array}$ & $\begin{array}{l}\text { The theory and practice of undergraduates in innovation and entrepreneurship } \\
\text { education are disconnected. Most college students have rich theoretical } \\
\text { knowledge and insufficient practical skills. Most of the university students' } \\
\text { learning places are limited to classrooms and classrooms. Although some } \\
\text { entrepreneurial design competitions are also held, they are not implemented in } \\
\text { practice. There are fewer innovation and entrepreneurship training bases. }\end{array}$ \\
\hline $\begin{array}{l}\text { The university } \\
\text { education model } \\
\text { suppresses the } \\
\text { development of } \\
\text { innovation and } \\
\text { entrepreneurship. }\end{array}$ & $\begin{array}{l}\text { education mode, pay too much attention to the cultiv } \\
\text { professional knowledge, and pay less attention to } \\
\text { entrepreneurial education. They also pay less attention t } \\
\text { teaching and training in entrepreneurship, and neglect the cl }\end{array}$ \\
\hline $\begin{array}{l}\text { University } \\
\text { innovation and } \\
\text { entrepreneurship } \\
\text { education system is } \\
\text { not mature enough, } \\
\text { lack of strong policy } \\
\text { guidance. }\end{array}$ & $\begin{array}{l}\text { me colleges and universities do not include innovation and entrepreneurship } \\
\text { ucation in the same position as professional education, and lack support and } \\
\text { entation policies for innovation and entrepreneurship education. Some } \\
\text { leges and universities did not incorporate entrepreneurship courses into the } \\
\text { mpulsory credits category, but only as an elective course. Schools do not pay } \\
\text { ough attention to innovation and entrepreneurship education, school } \\
\text { lovation and entrepreneurship atmosphere is not enough, some laboratories, } \\
\text { actice bases and other forms of innovation and entrepreneurship support for } \\
\text { lege students. }\end{array}$ \\
\hline
\end{tabular}

\section{The Measures to Improve College Students' Abilities in Innovation and Entrepreneurship from the Perspective of School}

The measures to improve college students' abilities in innovation and entrepreneurship from the perspective of school are shown in Table $2[4,5]$. 
Table 2 The measures to improve college students' abilities in innovation and entrepreneurship from the perspective of school

\begin{tabular}{|c|c|}
\hline Improvement measures & Specific description \\
\hline $\begin{array}{l}\text { Universities should create a } \\
\text { comprehensive innovation and } \\
\text { entrepreneurship } \\
\text { system. }\end{array}$ & $\begin{array}{l}\text { To combine the professional quality education of undergraduates } \\
\text { with innovation and entrepreneurship education, adopt a } \\
\text { combination of disciplines and majors, and hold seminars in forms } \\
\text { and entrepreneurship education. Adhering to the combination of } \\
\text { science and technology activities and classroom teaching to } \\
\text { encourage and support college students to participate in various } \\
\text { social activities for innovation and entrepreneurship. }\end{array}$ \\
\hline $\begin{array}{l}\text { Strengthen the building of a } \\
\text { faculty for innovation and } \\
\text { entrepreneurship education. }\end{array}$ & $\begin{array}{l}\text { Colleges and universities should take measures to provide } \\
\text { specialized training for innovators and entrepreneurial instructors, } \\
\text { encourage teachers to actively participate in academic conferences } \\
\text { on innovation and entrepreneurship, visit high-tech enterprises, } \\
\text { improve their own innovative thinking and innovative spirit, and } \\
\text { formulate relevant incentive policies to encourage teachers to guide } \\
\text { college students in innovation and entrepreneurship. Hiring } \\
\text { successful entrepreneurs from the society as visiting professors to } \\
\text { teach entrepreneurship skills and knowledge for college students. }\end{array}$ \\
\hline $\begin{array}{l}\text { Actively carry out the construction } \\
\text { of practical conditions for } \\
\text { innovation and entrepreneurship. }\end{array}$ & $\begin{array}{l}\text { Colleges and universities should attach importance to the } \\
\text { construction of practical conditions for innovation and } \\
\text { entrepreneurship, college experimental teaching centers, and open } \\
\text { laboratories to provide innovation and entrepreneurship students } \\
\text { with a platform for innovation and entrepreneurship. A special } \\
\text { student entrepreneurship agency has been set up in the university } \\
\text { to organize innovative and entrepreneurial college students to use } \\
\text { resources such as innovation and entrepreneurship bases and } \\
\text { industrial parks inside and outside the school to carry out } \\
\text { innovation and entrepreneurship practices. }\end{array}$ \\
\hline $\begin{array}{l}\text { Establish and improve the } \\
\text { incentive mechanism for college } \\
\text { students' innovation. }\end{array}$ & $\begin{array}{l}\text { Colleges and universities shall encourage and encourage college } \\
\text { students to start their own businesses, support venture capital and } \\
\text { establishment of entrepreneurial sites for innovative and } \\
\text { entrepreneurial projects with a certain market prospect, and } \\
\text { provide certain spiritual and material rewards to instructors. Attract } \\
\text { more teachers and college students to practice innovation and } \\
\text { entrepreneurship. }\end{array}$ \\
\hline $\begin{array}{l}\text { Colleges and universities should } \\
\text { actively create innovative } \\
\text { entrepreneurship } \\
\text { atmosphere. }\end{array}$ & $\begin{array}{l}\text { University should create innovative entrepreneurial environments, } \\
\text { organize academic lectures related to innovation and } \\
\text { entrepreneurship, invite some famous teachers and experts to } \\
\text { make reports, and open up some entrepreneurship education } \\
\text { courses to familiarize students with the basic ideas and processes of } \\
\text { entrepreneurship, improve students' knowledge structure, and } \\
\text { develop students' knowledge. The spirit of scientific exploration } \\
\text { has ignited students' entrepreneurial passion. }\end{array}$ \\
\hline $\begin{array}{l}\text { Supporting college students to } \\
\text { actively participate in societies and } \\
\text { competitions related to innovation } \\
\text { and entrepreneurship }\end{array}$ & $\begin{array}{l}\text { Universities through college student organizations to carry out a } \\
\text { variety of innovative entrepreneurial activities to stimulate students } \\
\text { to participate in innovation and entrepreneurial activity } \\
\text { enthusiasm, to develop students' sense of competition, cooperation } \\
\text { and awareness of innovation, create a good atmosphere for } \\
\text { innovation and entrepreneurship. }\end{array}$ \\
\hline
\end{tabular}




\section{Analysis of Factors Affecting College Students' Innovation and Entrepreneurship from the Perspective of Society}

The factors affecting college students' abilities in innovation and entrepreneurship from the perspective of society are shown in Table $3[6,7]$.

Table 3 The factors affecting college students' abilities in innovation and entrepreneurship from the perspective of society

\begin{tabular}{|l|l|}
\hline Influencing factors & \multicolumn{1}{|c|}{ Specific description } \\
\hline $\begin{array}{l}\text { The social } \\
\text { innovation and } \\
\text { entrepreneurship } \\
\text { environment needs } \\
\text { to be improved. }\end{array}$ & $\begin{array}{l}\text { The media and the existence of over-promoting the feasibility of college } \\
\text { students' self-employment, the social tolerance of college students for } \\
\text { innovation and entrepreneurship failure is relatively low, which makes college } \\
\text { students in the innovation and entrepreneurship to increase pressure. The } \\
\text { society does not form a social atmosphere that respects and supports college } \\
\text { students' innovation and entrepreneurship. In the process of innovation and } \\
\text { entrepreneurship, college students encounter social financing difficulties, site } \\
\text { constraints, and inadequate implementation of national policy support. }\end{array}$ \\
\hline $\begin{array}{l}\text { University students } \\
\text { lack the necessary } \\
\text { family support. }\end{array}$ & $\begin{array}{l}\text { Students with relatively good family background have relatively low } \\
\text { entrepreneurial tendencies or entrepreneurial awareness. Parents do not have } \\
\text { corresponding entrepreneurial experiences and their own entrepreneurial } \\
\text { awareness will be relatively low. Many families are unable or unwilling to invest } \\
\text { in supporting their children's innovation and entrepreneurial activities. For some } \\
\text { parents of students, they are deeply influenced by traditional ideas and do not } \\
\text { support their children in starting a business. }\end{array}$ \\
\hline $\begin{array}{l}\text { The implementation } \\
\text { of entrepreneurial } \\
\text { support policies is } \\
\text { not in place. }\end{array}$ & $\begin{array}{l}\text { Although the state has introduced many laws and policies that support college } \\
\text { students' self-employment, these implementation processes are difficult. Due to } \\
\text { the unbalanced economic and social development in various regions, different } \\
\text { characteristics of colleges and universities, the implementation of } \\
\text { entrepreneurial policy support is relatively low, and the risk investment } \\
\text { environment is poor, and the relevant innovation and entrepreneurship policies } \\
\text { have not yet exerted effective use. }\end{array}$ \\
\hline
\end{tabular}

\section{The Measures to Improve College Students' Abilities in Innovation and Entrepreneurship from the Perspective of Society}

The measures to improve college students' abilities in innovation and entrepreneurship from the perspective of society are shown in Table $4[7,8]$. 
Table 4 The measures to improve college students' abilities in innovation and entrepreneurship from the perspective of society

\begin{tabular}{|c|c|}
\hline $\begin{array}{l}\text { Improvement } \\
\text { measures }\end{array}$ & Specific description \\
\hline $\begin{array}{l}\text { Build a public } \\
\text { professional } \\
\text { service platform. }\end{array}$ & $\begin{array}{l}\text { The government should consciously build a public professional service platform } \\
\text { that integrates capital, technology, human resources, and knowledge for college } \\
\text { students, and create a relaxed and harmonious college student innovation and } \\
\text { entrepreneurship service environment. The government must establish a platform } \\
\text { for innovation and entrepreneurship technology services and information } \\
\text { network services to accelerate the exchange of public information and mobilize } \\
\text { all resources of the society to serve students in innovation and entrepreneurship. }\end{array}$ \\
\hline $\begin{array}{l}\text { Optimize } \\
\text { innovation and } \\
\text { venture capital } \\
\text { financing system. }\end{array}$ & $\begin{array}{l}\text { To establish a certain degree of innovation and venture capital in colleges and } \\
\text { universities, the government must continuously improve the environment for } \\
\text { innovation and entrepreneurship financing of university students and strengthen } \\
\text { the financial support for college students in innovation and entrepreneurship. We } \\
\text { will increase the propaganda of college students' innovation and entrepreneurship } \\
\text { loans, formulate policy loans for college students innovation and } \\
\text { entrepreneurship, and implement policies such as tax deductions and exemptions } \\
\text { for college students in their own businesses, provision of small secured loans, and } \\
\text { implementation of subsidies for innovation and entrepreneurship. }\end{array}$ \\
\hline $\begin{array}{l}\text { Strengthen the } \\
\text { construction of } \\
\text { innovation and } \\
\text { entrepreneurship } \\
\text { practice bases. }\end{array}$ & $\begin{array}{l}\text { The college students' business practice base is an important practical platform for } \\
\text { carrying out innovation and entrepreneurship education and promoting college } \\
\text { students to start their own businesses. On the one hand, the entrepreneurial base } \\
\text { can provide college students with innovations and entrepreneurship with venues, } \\
\text { equipment, and other material support; on the other hand, they can combine } \\
\text { superior resources such as universities and research institutes to promote the } \\
\text { transformation of technological innovation achievements. The government } \\
\text { should strengthen the construction of a business practice base, reduce the risk of } \\
\text { college students' innovation and entrepreneurship, and improve the success rate } \\
\text { of college students' innovation and entrepreneurship. }\end{array}$ \\
\hline $\begin{array}{l}\text { Create a good } \\
\text { social } \\
\text { environment for } \\
\text { innovation and } \\
\text { entrepreneurship. }\end{array}$ & $\begin{array}{l}\text { The government should play a coordinating and guiding role, give full play to the } \\
\text { forces of the government, enterprises, and social organizations, and set up an } \\
\text { innovation and entrepreneurship development fund to provide policy and } \\
\text { financial support for college students' innovation and entrepreneurship. Create a } \\
\text { social environment of innovation and entrepreneurship that encourages } \\
\text { innovation and tolerance for failure in society as a whole. Encourage enterprises } \\
\text { to provide assistance for college students in innovation and entrepreneurship in } \\
\text { terms of financial support, platform construction, and practical exercises. }\end{array}$ \\
\hline $\begin{array}{l}\text { Parents should } \\
\text { understand and } \\
\text { support college } \\
\text { students' } \\
\text { innovation and } \\
\text { entrepreneurship. }\end{array}$ & $\begin{array}{l}\text { Parents should change their minds, encourage and support the children to start } \\
\text { their own businesses after graduation, and care more about the self-employment } \\
\text { of college students in their own lives. Under the conditions of the family } \\
\text { economy permit, college students should be provided with certain start-up funds. } \\
\text { In cultivating the innovative and entrepreneurial ability of college students, the } \\
\text { family's sense of innovation has a driving force to form and promote } \\
\text { entrepreneurial behavior. }\end{array}$ \\
\hline
\end{tabular}

\section{Summary}

To carry out innovation and entrepreneurship education in ordinary colleges and universities is a strategic measure to build an innovative country and a powerful human resource. From the perspective 
of school and society, it is of great practical significance to analyze the influencing factors of college students' abilities in innovation and entrepreneurship and to put forward measures for improvement.

\section{Acknowledgements}

This work was sponsored by Tianjin Agricultural University Teachers Education Reform and Innovation to Guide the Development of the Project No. 20170904 and Tianjin Agricultural University Education and Teaching Reform Project No. 2016-B-17.

\section{References}

[1] Y. Tang: Journal of Changchun Education Institute, Vol. 31 (2015) No.9, p.37-38.

[2] L. Han: CHTNESE UNTVERSTTY TECHNOLOGY TRANSFER, (2017) No.1, p.121-123.

[3] H. LAN: CHINA ADULT EDUCATION, (2016) No.15, p.80-81.

[4] X.W. Li: JOURNAL OF LONGYAN UNIVERSITY, Vol. 34 (2016) No.1, p.84-87.

[5] K.L. Zhang: Theory and Practice of Education, Vol. 31 (2017) No.12, p.21-23.

[6] G.P. Xiao: CHINESE UNIVERSITY SCIENCE \& TECHNOLOGY, (2017) No.7, p.84-87.

[7] G.H. Huang: JOURNAL OF MINNAN NORMAL UNIVERSITY, Vol. 30 (2016) No.3, p.150 $-152$.

[8] Y.M. Kan: Journal of Jilin Teachers Institute of Engineering and Technology, Vol.30 (2014) No.12, p.30-31. 